\title{
Application of the maturity method to reinforced concrete roof slabs
}

\author{
Aplicação do método da maturidade \\ em lajes de cobertura
}

\author{
Roberto Luiz Curra ${ }^{1}$, Fernanda Pacheco ${ }^{2}$, Hinoel Zamis Ehrenbring ${ }^{2}$, \\ Roberto Christ ${ }^{3}$, Jeferson Ost Patzlaff ${ }^{4}$, Rafael Trevisan ${ }^{5}$ Bernardo Fonseca Tutikian ${ }^{3}$
}

\author{
${ }^{1}$ Curra Engenharia, Av. Pátria, 1311, CEP: 90230-071, Porto Alegre, RS, Brasil \\ ${ }^{2}$ Professor, Unisinos, Instituto Tecnológico em desempenho e construção civil (itt Performance), Avenida Unisinos, 950 , \\ CEP: 93022-750, São Leopoldo, RS, Brasil. \\ ${ }^{3}$ Professor, Universidad de La Costa, Departamento de Engenharia Civil e Ambiental, Calle 58 \# 55-66, Barranquilla, \\ Colômbia \\ ${ }^{4}$ Professor, Unisinos, Avenida Unisinos, 950, CEP: 93022-750, São Leopoldo, RS, Brasil, CEP: 93022-750. \\ ${ }^{5}$ Engenheiro Civil, Maricler construtora, Av. Brasil, 53 - Centro, Portão - RS, 93180-000, Brasil. \\ e-mail: engenheiro@ robertocurra.com, fernandapache@unisinos.br; hzamis@unisinos.br, rchrist@unisinos.br; \\ bftutikian@unisinos.br, jefersonop@unisinos.br, rafael.trevisan94@gmail.com
}

\begin{abstract}
The maturity method is a procedure that associates the evolution of the temperature of concrete cast to the structure and the evolution of its hardened state properties like compressive strength, usually at early ages. Its use is justified when safety and agility are required for activities like prestressing, shoring removal, demolding and low temperature concrete curing analysis. Temperate regions are known for having lower temperatures during the winter, which can delay concrete strength gains. The aim of this study was to apply the maturity method to a reinforced concrete structure located in Southern Brazil in industrial construction. It was noted that the concrete, despite being expected to reach $30 \mathrm{MPa}$ at 28 days, managed to reach $70 \%$ of the strength at 8.5 days for slab 1. Slab 2, whose function was to support garners 4,5 and 6 , presented the data at 4.4 days, it being possible to measure such property using the maturity method.
\end{abstract}

Keywords: maturity method, concrete, compressive strength.

\section{RESUMO}

O método da maturidade é um procedimento que associa a evolução da temperatura do concreto e o avanço de suas propriedades no estado endurecido, como a resistência à compressão, geralmente em idades iniciais. Sua aplicação é justificada quando se requer segurança e agilidade para tarefas de construção, como a protensão, a remoção do escoramento, o desmolde e a cura de concreto em baixas temperaturas. As regiões de clima temperado são conhecidas por apresentar temperaturas mais baixas durante o inverno, o que pode retardar o ganho de resistência do concreto. Este estudo aplicou o método de maturidade em uma estrutura de concreto armado localizada no Sul do Brasil, em uma construção industrial. Se observou que o concreto, do qual se esperava o alcance de $30 \mathrm{MPa}$ aos 28 dias, chegou a alcançar 70\% da resistência com 8,5 dias para a laje 1 e em 4,4 dias para a laje 2, sendo possível mensurar tal propriedade utilizando o método da maturidade.

Palavras-chave: concreto, durabilidade, análise estatística, especificação técnica.

\section{INTRODUCTION}

Compressive strength is the most relevant property that regards load-bearing capacity and structural behavior of concretes [1]. Checking if a certain strength or its evolution have been met is commonly done through destructive methods, as technical standards suggest [2]. This analysis measures strength gains of concretes at varying ages to assess if the parameters specified in design have been reached, or even to support the performance of tasks such as demolding, shoring removal, prestressing, and others.

The compressive strength of concrete is influenced by several factors, such as: concrete dosage, cement particle-size distribution, type of cement, minerals or chemical substances added to the mixture, molding of 
elements, curing, water/cement ratio and curing temperature [3]. Among these factors, the only one that can't be controlled under real structure casting situations is the temperature of exposure and curing of the elements.

Many authors debate how temperature impacts strength gains and concrete hydration [4-6]. Studies show that compressive strength tends to be higher when the concrete is exposed to higher curing temperatures [7]. Fig. 1 depicts a study developed with the same composition, varying water/cement ration and curing temperatures.

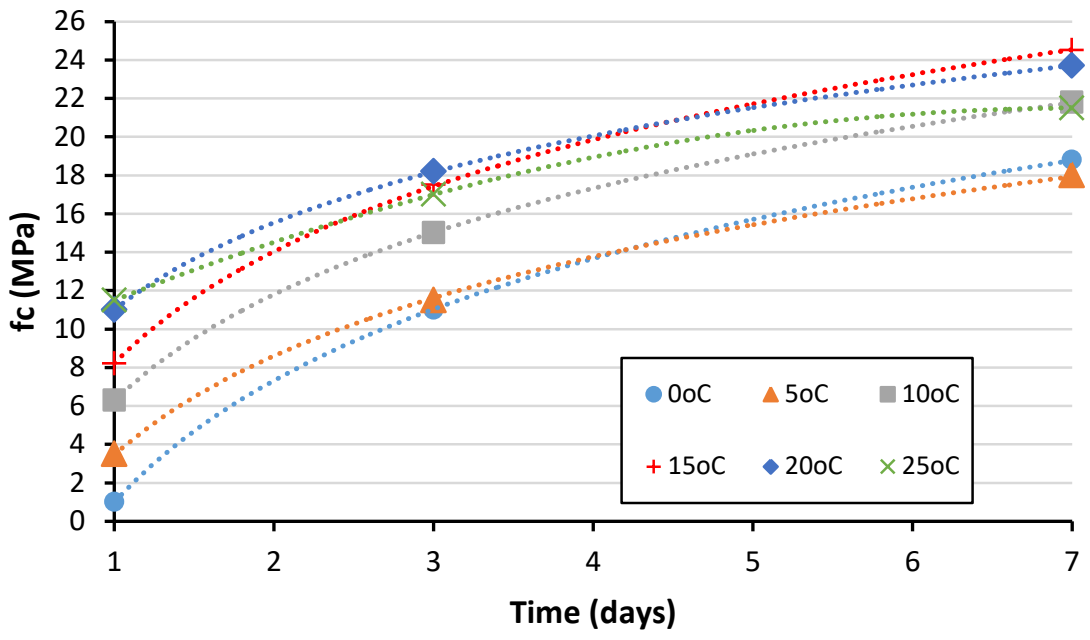

Figure 1: Effects of curing temperature on compressive strength

Figure 1 denotes positive influence of high temperatures on the development of initial strength of concrete, although this influence turns negative at advanced ages. BURG [4] and LAGUNA and IKEMATSU [8] found values that agree with the presented.

It is possible for controllable factors to forecast the behavior of structures concerning their compressive strength and durability based on parameters of mixing and dosage, as technical standards state [9-11]. Temperature must be a relevant parameter in this estimation though, as strength gains of concrete are affected by both the number of reagents and heat intensity [12]. These authors also affirm that increasing the temperature makes molecules move faster and with more energy, increasing chemical reaction rates.

Given its relevance, the influence of temperature on compressive strength of concretes started being studied around 1950 in England, with the intent of developing accelerate curing processes for the precast concrete industry [13-16].

Such study resulted in the maturity method, which is based on the transformation of real-time measurements of temperature when determining the strength of concrete pieces [17]. This method has been used as a non-destructive test that grants safety and agility for building processes [18]. Some of the main motivations for this test are assessing the compressive strength needed for demolding and shoring removal, prestressing concrete pieces and to analyze temperature and time necessary for specific curing processes of the precast concrete industry $[19,20]$.

Its effectiveness is due to considering temperature as the most relevant parameter for concrete strength at early ages [21]. LI et al. [22] evaluated the formation of cracks on concretes for dams by the maturity method, considering summer and winter situations. As per these authors, temperature exerts significant influence not only on concrete hydration, but on the existence and magnitude of cracks as well. The maturity method can be applied following two models, being Nurse-Saul's and one based on the Arrhenius Law. In the United States, the Norse-Saul model is the used most often due mostly to its simplicity, although the model based on the Arrhenius law is more precise scientifically [23].

The law of Arrhenius is used for describing the effect of temperature on the reaction rate of a certain chemical reaction [12]. The application of the maturity method based on the law of Arrhenius was proposed by HANSEN and PETERSON [24] in the first place. These authors presented an equation that could determine the equivalent age of concrete as a function of the temperature to which it was subjected.

Using this equation requires the determination of the activation energy of concrete, though. The activation energy was proposed by Syante Arrhenius in 1888 to explain why chemical reactions do not occur 
instantly when two reagents make physical contact [12]. This energy, for Arrhenius, comes from the minimum kinetic energy the reagents need to react with each other upon collision [16].

The procedure for determining activation energy of concrete is described by ASTM 1074-98 [25]. According to Carino [26], the materials and the mixture used make activation energy vary, whereas its values usually stand between $41 \mathrm{~kJ} / \mathrm{mol}$ and $67 \mathrm{~kJ} / \mathrm{mol}$. Due to this variation, PERES et al. [27] conducted a research to determine the activation energy of cements used in Brazil, whose results are presented in Table 1. It should be noted that these values are specific to those compositions and components.

Table 1: Activation energy (Ea) for Brazilian cements

\begin{tabular}{cccc}
\hline CEMENT TYPE & Ea (kJ/mol) & CEMENT TYPE & Ea (kJ/mol) \\
\hline CP-I-S & 35.4 & CP-III & 57.0 \\
\hline CP-II-F-32 & 31.4 & CP-IV & 50.4 \\
\hline CP-II-Z-32 & 31.3 & CP-V & 43.9 \\
\hline
\end{tabular}

Some software programs currently specialize in applying the maturity method, which can estimate activation energy from the temperature to which the concrete is exposed and its composition, as is the case of Con-Cure $\AA$.

As per National Ready Mixed Concrete [23], the maturity method should be applied considering the following steps:

- Determination of the strength-maturity relation for the concrete used in the structure. Check the temperature of specimens through sensors and keep track of the advances of compressive strength to plot the maturity curves (by Nurse-saul or Arnheius);

- Measurement and recording of the hystory of temperature of the structure's concrete elements by installing sensors on strategic spots (less favorable regarding solar energy or the last volumes to be added to the elements);

- Calculation of the maturity index from the samples' recordings of temperature and age;

- Awareness or experimental obtention of the activation energy, which varies with respect to the type of cement used;

- "In loco" estimation of the concrete compressive strength based on temperature, maturity index and the prestated relation between strength and concrete maturity.

The method has some limitations that should be considered during application. Galobardes et al. [18] stress that the maturity method should be set for each concrete composition, evaluating the relation between mechanical properties and strength gains for materials in comparison with the mixtures kept under the standard condition.

KIM and RENS [28] point out that the test procedure is dictated by ASTM C1073 [29] with the following limitations: (a) Concrete must be kept under conditions that allow its hydration; (b) The method does not contemplate the effects of the initial temperature on final strength; (c) This method must be complemented by other concrete analyses; (d) The concrete used in the structure is not representative of the one used in laboratory for calibration due to the alterations of concrete, its heterogeneity, amount of air and dosage precision; (e) High temperatures at early ages shall result in an incorrect forecast of the strength at final ages; (f) The use of wrongful data recordings of temperature or activation energy, i.e. inconsistent with the concrete evaluated, may lead to an incorrect compressive strength forecast.

Considering the Southern region of Brazil, which is known for its well-defined seasons and mountain region with lower temperatures, this study monitored concreting processes that occurred under these conditions in the city of Bento Gonçalves, seeking construction safety and the concreting of reinforced concrete slabs, assuring quality on the conduction of tasks from the construction process to meet design specifications.

\section{EXPERIMENTAL PROCEDURE}




\subsection{Materials}

This study revolved around the analysis of strength with regards to temperature of concrete with compressive strength of $30 \mathrm{MPa}$ and slump class of $100 \mathrm{~mm}$. The demolding procedure specified a minimum strength of $21 \mathrm{MPa}$, so the maturity method was used to determine the time needed to obtain this compressive strength and thus release the demolding process. Table 2 presents the characteristics of the concrete.

Table 2: Characteristics of concrete from structural elements

\begin{tabular}{|c|c|c|c|}
\hline MATERIAL & TYPE & SPECIFIC GRAVITY $\left(\mathbf{k g} / \mathbf{d m}^{3}\right)$ & $\begin{array}{c}\text { QUANTITY } \\
\left(\mathrm{kg} / \mathrm{m}^{3}\right)\end{array}$ \\
\hline Cement & CP-II-F-40 & 3.11 & 282 \\
\hline Pozzolan & Fly ash & 2.3 & 94 \\
\hline Crushed sand & Medium & 2.69 & 709 \\
\hline \multirow{3}{*}{ Gravel } & Maximum size of $9.5 \mathrm{~mm}$ & \multirow{3}{*}{2.69} & 100 \\
\hline & Maximum size of $19 \mathrm{~mm}$ & & 551 \\
\hline & Maximum size of $25 \mathrm{~mm}$ & & 351 \\
\hline Chemical admixture & Multifunctional plasticizer & 1.2 & 3.01 \\
\hline
\end{tabular}

The elements were cast in two stages, being two slabs that supported 3 garners each (slab 1 supported garners 1, 2 and 3, while slab 2 supported garners 4, 5 and 6). The slabs measured $10 \times 30 \times 1.10 \mathrm{~m}$, constituting $330 \mathrm{~m}^{3}$ of concrete each. The coarse aggregate used had three maximum aggregate sizes to increase the mixture's packing. Fig. 2 depicts the study site.

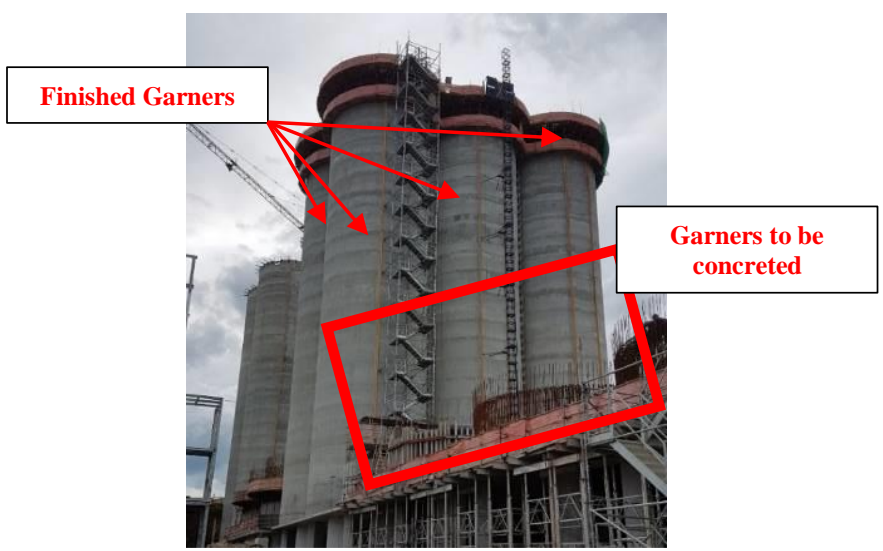

Figure 2: Indication of the concrete place

\subsection{Place of Application}

The city where the study was developed presents humid subtropical climate, with well-defined seasons, cold winters and hot summers, in which the month of July displays the lowest average temperature of the year, $13^{\circ} \mathrm{C}$, which is when the concreting took place. Humidity is high, with yearly mean of $70 \%$. The methods were applied following these steps:

a) Analysis of compressive strength evolution under the condition of temperature controlled in laboratory;

b) Instrumentation and observation of temperatures along the concreting process of both slabs that were analyzed, as Fig. 3 shows;

c) Estimation of compressive strength in real time through the software program named Con-Cure ${ }^{\circledR}$. 


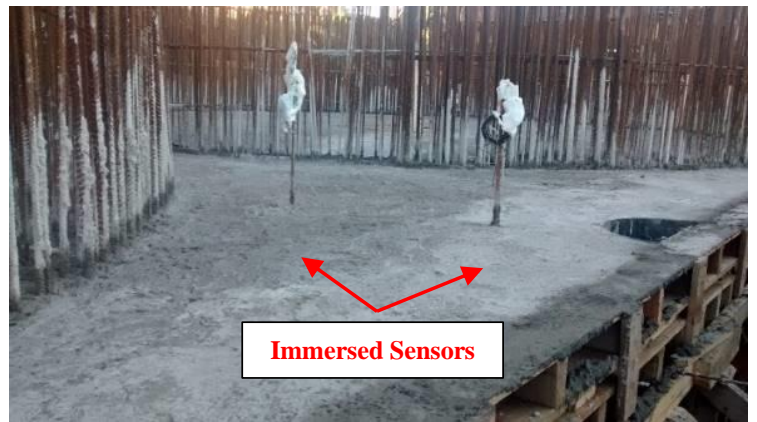

Figure 3: Concreting site (monitoring slab).

For the first stage, 24 specimens were molded to be tested for compressive strength at 1, 2, 3, 5, 7, 14, 28 and 63 days, considering three samples for each age. These samples were stored in a climatic test room under controlled temperature and humidity conditions of $23 \pm 2^{\circ} \mathrm{C}$ and $65 \pm 5 \%$.

Being aware of the evolution of this strength, the concreting procedures were performed on the real structure, counting with instrumentation by temperature sensors. These sensors could be removed with plastic hoses and were installed at the depths of $0.20 \mathrm{~m}, 0.35 \mathrm{~m}$ and $0.55 \mathrm{~m}$, being these the positions at garner 1 , garner 2 and garner 3 on slab 1 and garners 4, 5 and 6 on slab 2. Data loggers were attached to these sensors and the configuration adopted considered that temperature should be recorded every minute or every time concrete temperature varied $1^{\circ} \mathrm{C}$.

The activation energy was determined by the software and the composition of the concrete used. Results pointed out equivalent curing periods, as YIKICI and CHAN [30] had achieved, translating the relation between real curing and gain or delay from exposure temperatures of the structural element.

\section{RESULTS}

\subsection{Initial Evaluation of Concrete and System Calibration}

Prior to the application of the method, the concrete composition maturity curve was checked. Fig. 4 plots these data for better visualization. At 28 days, the mixture had not reached its characteristic strength, assessed only at the 63 days. It should be noted, though, that this evolution considers an isothermal curing condition, hence eliminating the influence of temperature.

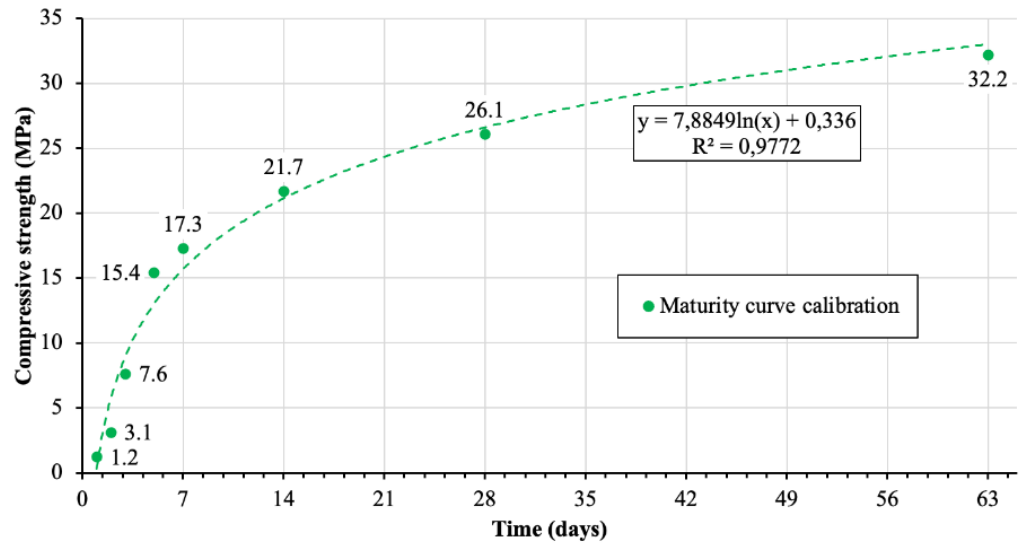

Figure 4: Evolution of concrete strength under isothermal condition

\subsection{Monitoring the Concreting Processes}

The first concreting embraced slab 1 (support of garners 1, 2 and 3). Its data are presented in Table 3, and it yielded the compressive strength growth results depicted in Fig. 5-7. The concreting processes were performed during winter, with temperatures between -3 and $17.5^{\circ} \mathrm{C}$. The activation energy was $39.1 \mathrm{~kJ} / \mathrm{mol}$. 
Table 3: Concrete monitoring

\begin{tabular}{cccccc}
\hline SENSOR & GARNER & $\begin{array}{c}\text { INITIAL } \\
\text { READING }\end{array}$ & $\begin{array}{c}\text { CURING TIME } \\
\text { (days) }\end{array}$ & $\begin{array}{c}\text { EQUIVALENT AGE } \\
\text { (days) }\end{array}$ & $\begin{array}{c}\text { ESTIMATED STRENGHT } \\
\text { (MPa) }\end{array}$ \\
\hline 1 & 01 & $16 \mathrm{~h} 55$ & 8.5 & 13.9 & 21.2 \\
\hline 2 & 02 & $15 \mathrm{~h} 16$ & 6.5 & 14.1 & 21.3 \\
\hline 3 & 03 & $09 \mathrm{~h} 14$ & 4 & 14.2 & 21.4 \\
\hline
\end{tabular}

As observed in Fig. 5a, the temperature of the concrete element throughout the period of 8.5 real curing days remained between $17.3^{\circ} \mathrm{C}$ and $36.3^{\circ} \mathrm{C}$. Fig. $5 \mathrm{~b}$ showed that sensor 1 , placed at a depth of $0.20 \mathrm{~m}$, presented compressive strength of $21.2 \mathrm{MPa}$ after 8.5 days of curing, which is equivalent to the strength of the specimen cured for 13.9 days in laboratory.

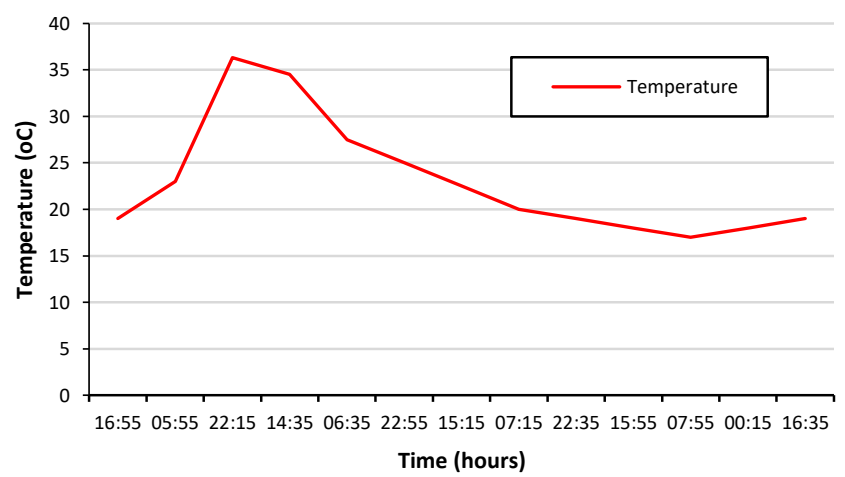

(a) temperature for 8.5 days / Max: $36.3^{\circ} \mathrm{C} / \mathrm{Min}: 17.3^{\circ} \mathrm{C}$

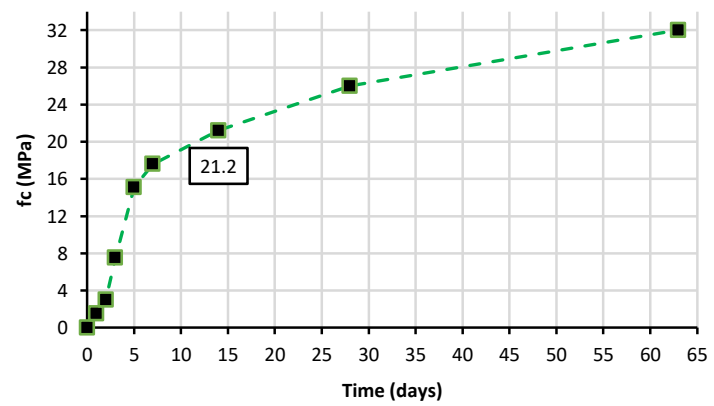

(b) strength and equivalent age (at 13.9 days)

Figure 5: Temperatures and concrete strength for sensor $1-0.25 \mathrm{~m}$

Fig. 6 shows the data for slab 1, on the position above garner 2. The second sensor was installed $0.35 \mathrm{~m}$ deep onto garner 2 and indicated a strength of $21.3 \mathrm{MPa}$ at 6.5 days of curing, value that was expected to have been reached after 14.1 days of curing, as the specimen had been cured in laboratory. It was noted that compressive strength was higher for this sensor fixed more deeply. 


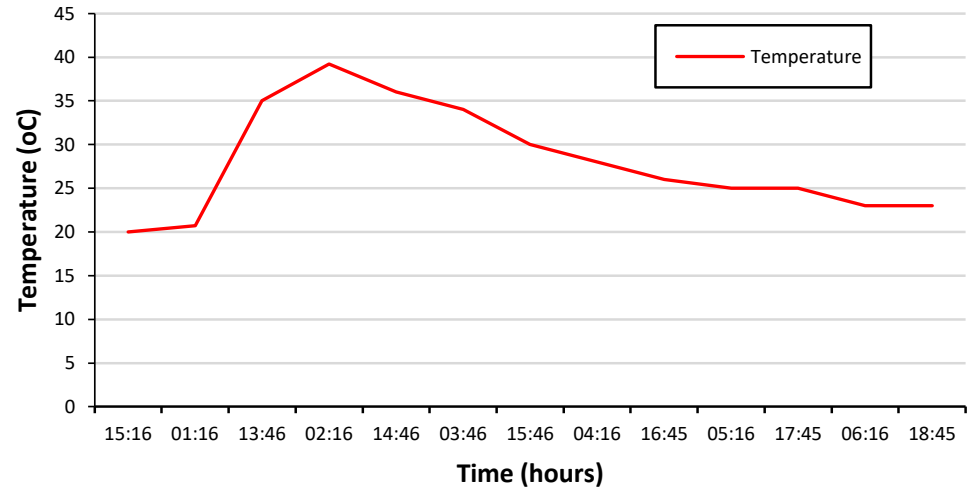

(a) temperature for 6.5 days / Max: $39.2^{\circ} \mathrm{C} / \mathrm{Min}: 19.3^{\circ} \mathrm{C}$

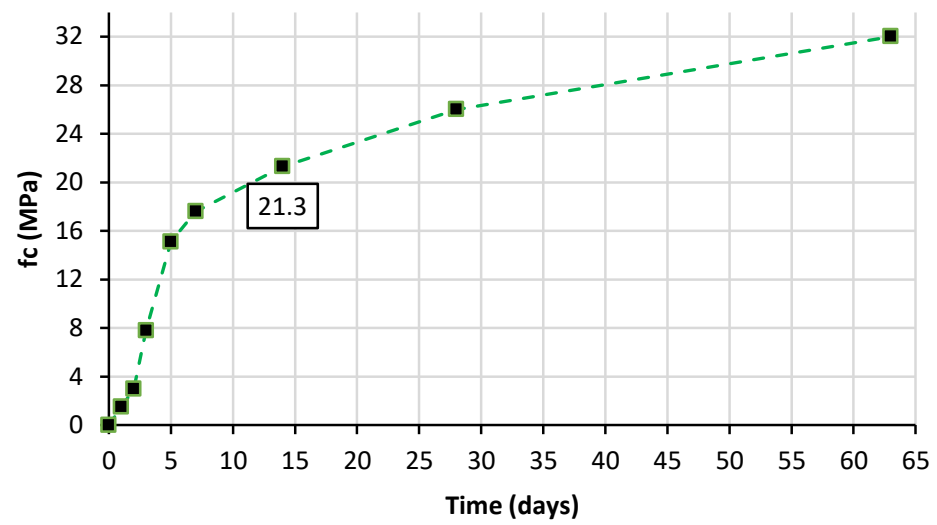

(b) strength and equivalent age (at 14.1 days)

Figure 6: Temperatures and concrete strength for sensor $2-0.35 \mathrm{~m}$

The third sensor was at a depth of $0.55 \mathrm{~m}$ on garner 3 and its data are presented in Fig. 7. This sensor spotted a strength of $21.4 \mathrm{MPa}$ after mere 4 days of curing, strength that was expected for 14.1 days in laboratory. Once more, higher mechanical strength was reached as the depth increased.

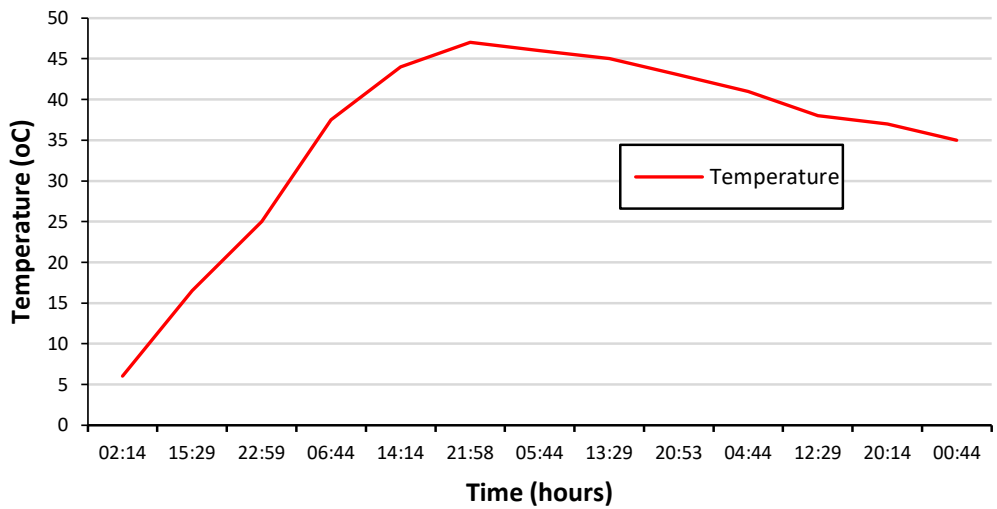

(a) temperature for 4.0 days / Max: $47.0^{\circ} \mathrm{C} / \mathrm{Min}: 6.1^{\circ} \mathrm{C}$ 


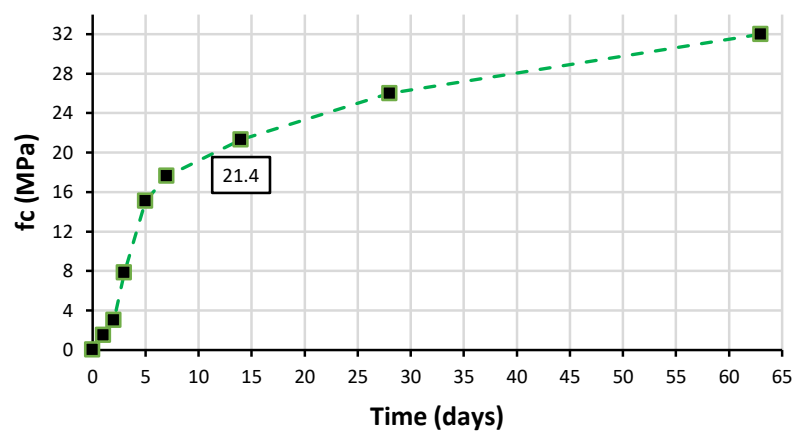

(b) strength and equivalent age (at 14.2 days)

Figure 7: Temperatures and concrete strength for sensor $3-0.55 \mathrm{~m}$

The results coincide with the literature, as concreting processes of greater volumes accumulate heat released by cement hydration reactions that increase concrete temperature [5]. So, despite being less influenced by room temperature or solar incidence, the heat from volume hydration turns out to be more relevant.

It was generally observed that, even with lower room temperatures $\left(-1^{\circ} \mathrm{C}\right.$ up to $\left.17.5^{\circ} \mathrm{C}\right)$, compressive strength evolved faster than the expected in laboratory, as depths of $0.25 \mathrm{~m}, 0.35 \mathrm{~m}$ and $0.55 \mathrm{~m}$ displayed equivalent curing periods of $14.9,14.1$ and 14.2 days, which are lower than the real values of $8.5,6.5$ and 4 days, respectively.

The results for the second concreting are presented in Fig. 8-10, considering the respective bases of garners 4,5 , and 6 . The temperatures remained between 7 and $24{ }^{\circ} \mathrm{C}$ during the concreting.

Table 4: Compressive strength results- Monitoring the Concreting Processes

\begin{tabular}{cccccc}
\hline SENSOR & GARNER & $\begin{array}{c}\text { INITIAL } \\
\text { REAADING }\end{array}$ & $\begin{array}{c}\text { CURING TIME } \\
\text { (days) }\end{array}$ & $\begin{array}{c}\text { EQUIVALENT AGE } \\
\text { (days) }\end{array}$ & $\begin{array}{c}\text { ESTIMATED STRENGHT } \\
\text { (MPa) }\end{array}$ \\
\hline 1 & 04 & $13 \mathrm{~h} 22$ & 4.4 & 14.0 & 21.3 \\
\hline 2 & 05 & $11 \mathrm{~h} 17$ & 3.0 & 13.6 & 21.1 \\
\hline 3 & 06 & $11 \mathrm{~h} 12$ & 2.5 & 14.3 & 21.4 \\
\hline
\end{tabular}

Table 4 shows that the volume of concrete used for the second concreting presented faster strength development, as its strength reached $70 \%$ of its characteristic value within reduced real curing time. This occurred due to the room temperature now of this concreting, which varied between 7 and $24^{\circ} \mathrm{C}$. Fig. 8 refers to the depth of $0.25 \mathrm{~m}$ and points that, with only 4.4 days of real curing for the structure, the resulting strength was already of $70 \%$ of the value estimated for this concrete. Moreover, the temperature measurements of the pieces had minimum value of approximately $17.1^{\circ} \mathrm{C}$, while room temperature was $7^{\circ} \mathrm{C}$.

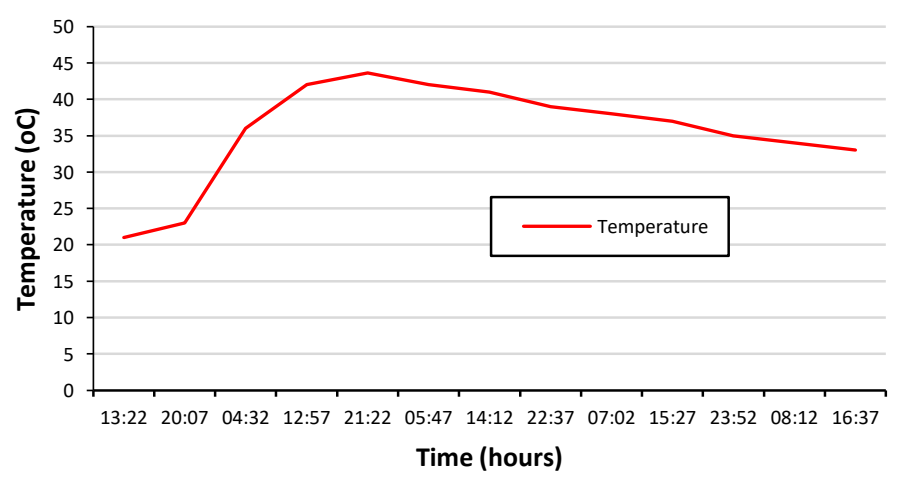


(a) temperature for 4.4 days / Max: $43.6^{\circ} \mathrm{C} / \mathrm{Min}: 18.9^{\circ} \mathrm{C}$

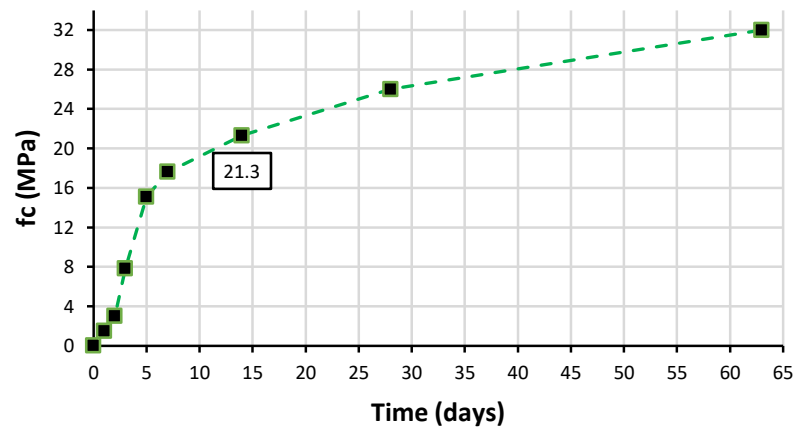

(b) strength and equivalent age (at 14.0 days)

Figure 8: Temperatures and concrete strength for sensor $4-0.25 \mathrm{~m}$

Continuing the exposition of results, Fig. 9 depicts the data from the sensor fixed at the depth of $0.35 \mathrm{~m}$ on garner 5. As observed in Fig. 9, regardless the reduced analysis age, it was forecast that $70 \%$ of the concrete strength would be reached at 3 days, being equivalent to the isothermal curing of 13.6 days. Fig. 10 finishes the presentation of results by pointing the measurement performed at 2.5 days for the sensor fixed $0.55 \mathrm{~m}$ from the surface of garner 6 .

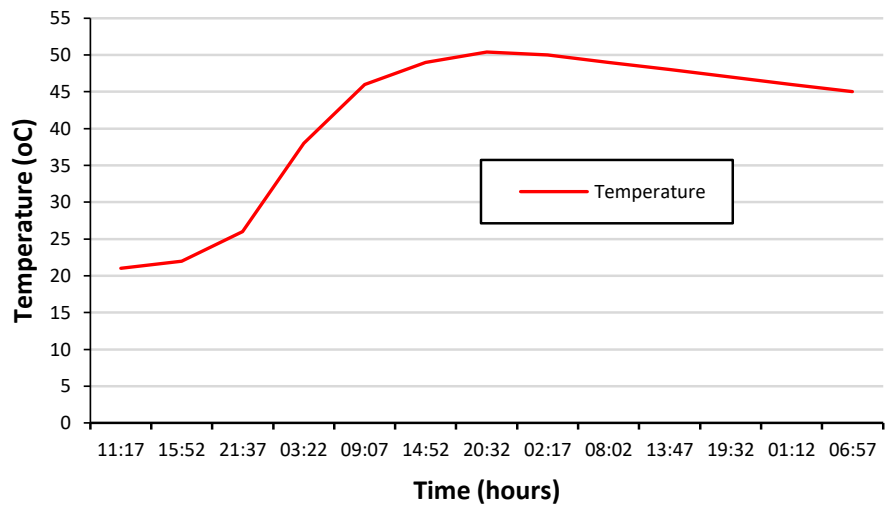

(a) temperature for 3.0 days / Max: $50.4^{\circ} \mathrm{C} / \mathrm{Min}: 17.0^{\circ} \mathrm{C}$

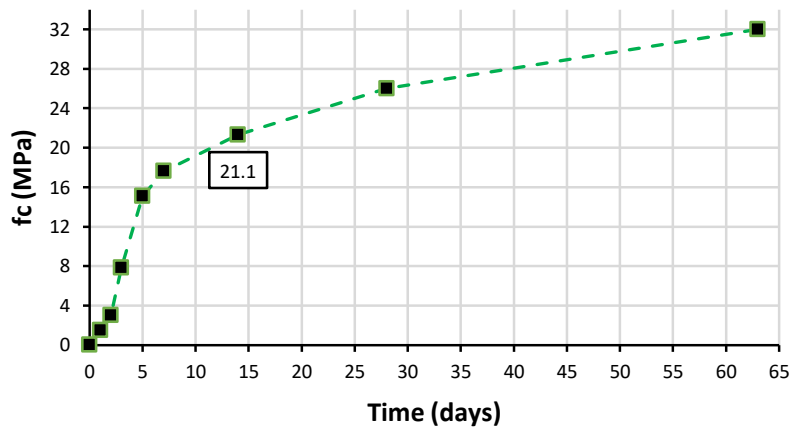

(b) strength and equivalent age (at 13.6 days)

Figure 9: Temperatures and concrete strength for sensor $5-0.35 \mathrm{~m}$ 


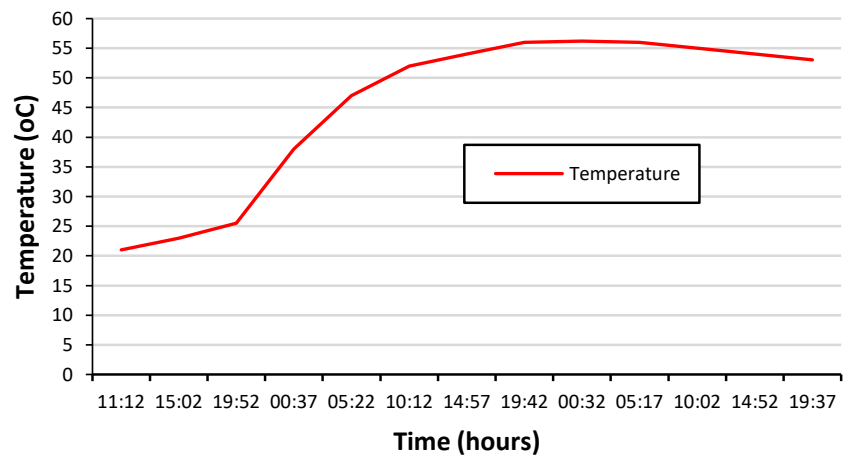

(a) temperature for 2.5 days / Max: $56.2^{\circ} \mathrm{C} / \mathrm{Min}: 17.1^{\circ} \mathrm{C}$

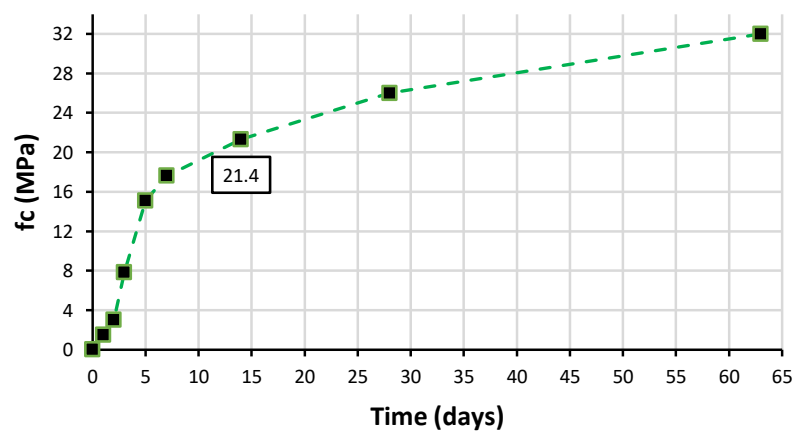

(b) strength and equivalent age (at 14.3 days)

Figure 10: Temperatures and concrete strength for sensor $6-0.55 \mathrm{~m}$

These results are in accordance with those from the first concreting, indicating that higher depths are less influenced by room temperature and solar incidence, despite the gain being compensated by the high volume of concrete. The resulting strength of $70 \%$ of the total value took place at 2.5 days for the analysis of the area of the slab pertaining garner 6.

Through a comparative analysis of both concreting processes that were monitored, it can be noted that the curing periods for the second were smaller, what may be related to higher room temperatures.

BENAICHA et al. [17] performed similar measurements on high-strength and self-consolidating concretes and found reduced equivalent curing periods with $5 \mathrm{~h}$ and $7.5 \mathrm{~h}$ required for these concretes to reach $10 \mathrm{MPa}$ respectively. Upon applying the maturity method to sprayed concrete, GALOBARDES et al. [18] found that the depth of the analysis, the materials and their volumes influenced their results, coinciding with the results pointed in this study.

Regarding the types of results achieved, SOUTSOS et al. [31] affirm that the analysis can be continued by relating curing temperature ranges and curing periods necessary to reach the strength defined in design.

\section{CONCLUSION}

The experimental procedure results point out the positive influence of the temperature, which acted as a catalyzer for strength gains. The exposure of concrete to high temperatures accelerates the cement hydration process and, consequently, gains in strength. in this study, a difference of 11.8 days was reached when comparing the actual cure (maturity method) with the equivalent age calculated by the method (laboratory cure). It was possible to indicate the relevant difference between the procedures adopted in the conventional technological control of concrete in specimens and the actual strength of the concrete cast in the element. Also, is worth notice that, besides external temperature, there was influence from cement hydration heat in this study, due to the high volume of concrete, which contributed to its maturity.

Moreover, it is evident that the breaking results for the specimens kept under isothermal condition are lower than the real strength development, confirming the positive contribution of temperature, even though it remained mild in the initial period of curing. It is considered that the results of this study are restricted to the type of cement used and, consequently, its activation energy, as well as the specific mix of concrete and the 
volume of the structural element. Minding only this method of control for buildings, it would act in favor of safety, may leading to a decrease of costs with equipment rental, hence benefited the logistics of construction and reducing the deadline for performing tasks.

\section{REFERENCES}

[1] ANDRADE, J.J.O, TUTIKIAN, B.F. Resistência mecânica do concreto. In: ISAIA, Geraldo Cechella. Concreto: Ciência e Tecnologia. São Paulo: IBRACON, 2011. Ch. 17. pp. 615-651.

[2] ASSOCIAÇÃO BRASILEIRA DE NORMAS TÉCNICAS. NBR 5739: Concreto - Ensaios de compressão de corpos-de-prova cilíndricos. Rio de Janeiro: Associação Brasileira de Normas Técnicas, 2007. $9 \mathrm{p}$.

[3] HASAN, M., KABIR, A. (2012). Early age tests to predict 28 days compressive strength of concrete. In: AWAM International conference on civil endineering \& geohazard information zonaton. Caspian Journal of applied sciences research.

[4] BURG, R.G., "The influence of casting and curing temperature on the properties of fresh and hardened concrete", Research and Development Bulletin RD113, Portland Cement Association, Skokie, Illlinois, U.S.A., 1996.

[5] MEHTA, P.K., MONTEIRO, P.J.M. (2014) Concreto: Microestrutura, propriedades e materiais, 2 ed, São Paulo, IBRACON, 2014 782p.

[6] NEVILLE, A.M. Propriedades do Concreto. $5^{\circ}$. ed. Porto Alegre: Bookman, 2015.

[7] CECCONELLO. V., TUTIKIAN, B.F. "The influence of low temperature on the evolution of concrete strength”. Revista Ibracon de estruturas e Materiais, v.5, n.1, pp.68-83, 2012.

[8] LAGUNA, L.A., IKEMATSU, P. “A influência da temperatura na desforma do concreto”. PINI web, 150. ed., 2009.

[9] EUROPEAN COMMITTEE FOR STANDARDIZARTION EN 1992-1-2: Eurocode 2: Design of concrete structures- Part 1-2- General rules- Structural fire design. Brussels: European Committee for Standardization, 2004.

[10] BUREAU OF INDIAN STANDARDS. IS 456: Plain and reinforced concrete- Code of practice- New Delhi: Bureau of Indian Standards, 2000.

[11] AUSTRALIAN STANDARD. AS 3600- Concrete structures. Sidney: Standards Australia Limited, 2009.

[12] BROWN, T.E., LEMAY, H.E., BURSTEN, B.E, et al.Chemistry: The Central Science. $11^{\circ}$ ed. Upper Saddle River, NJ: Pearson Education, Inc., 2009.

[13] MCINTOSH, J.D., 1949, “Electrical Curing of Concrete,” Magazine of Concrete Research, vol. 1, No. 1, pp. 21-28. January, 1949.

[14] NURSE, R.W., 1949, "Steam Curing of Concrete”, Magazine of Concrete Research, v. 1, v. 2, pp. 7988. 1949.

[15] SAUL, A.G.A. "Principles Underlying the Steam Curing of Concrete at Atmospheric Pressure," Magazine of Concrete Research, v. 2, v. 6, pp. 127-140. March, 1951.

[16] CARINO, N.J., LEW, H.S. The maturity method: from theory to application. NIST- National Institute of Standards and Technology. Proceedings of the 2001 Structures congress \& exposition, May 21-23, 19 p., 2001.

[17] BENAICHA, M., BURTSCHELL, Y., ALAOUI, A.H. "Prediction of compressive strength at early age of concrete. Application of maturity". Journal of building engineering, v. 6, pp.119-125. 2016.

[18] GAlOBARDES, I., CAVAlARO, S.H., GOODIER, C.I., et al. "Maturity method to predict the evolution of the properties of sprayed concrete". Construction and building materials, 79, pp. 357-369. 2015

[19] MALHOTRA, V.M., CARINO, N.J. "Handbook on nondestructive testing of concrete", Abingdon: CRC Press; 2004.

[20] ZADED, S.H.B., KIM, H., HOUNSELL, S., et al. Field study of concrete maturity methodology in cold weather. doi: 10.1061/(ASCE)0733-9364(2007)133:11(827). Journal of construction engineering and management., v. 133, n.11, pp. 827-835, 2007.

[21] LAPLANTE, P., ROUSSEL, S., LECRUX, S. "Technique maturométrique: la loi d’Arrhénius au service des chantiers", RILEM Publications, pp.323-342. 1998. 
[22] LI, Q., GUAN, J., WU, Z., et al. Equivalent maturity for ambient temperature effect on fracture parameters of site-casting dam concrete. Construction and building materials, pp. 293-308. 2016.

[23] NATIONAL READY MIXED CONCRETE ASSOCIATION - NRMCA. CIP 39 - "Maturity Methods to Estimate Concrete Strength”. 2006.

[24] HANSEN, F., PETERSEN, J. "Curing of Concrete Structures". CEB Information Bulletin, p. 42. May 1977.

[25] AMERICAN SOCIETY FOR TESTING AND MATERIALS - ASTM. C1074 - "Standard Practice for Estimating Concrete Strength by the Maturity Method", 2019.

[26] CARINO, N.J. "The maturity method". In: CRC Handbook on nondestructive testing of Concrete, V.M. Malhotra and N.J. Carino. Eds. CRC Press, pp. 101-146. 1991.

[27] PERES, L.D.P., BARBOSA, M.P., PINTO, R.C.A. "Aplicação do método da maturidade na avaliação da resistência à compressão de peças pré-moldadas". In: $1^{\circ}$ Encontro nacional de pesquisa-projeto-produção em concreto pré-moldado. São Carlos, SP, Brazil, 12p. 2005.

[28] KIM, T., RENS, L. "Concrete maturity method using variable temperature curing for normal-strength concrete mixes". II Theoretical study. Journal of materials in civil engineering. Vol 12, p. 735-741. 2008.

[29] AMERICAN SOCIETY FOR TESTING AND MATERIALS - ASTM. C1073 - "Standard Test Method for Hydraulic Activity of Slag Cement by Reaction with Alkali”, 2018.

[30] YIKICI, T.A., CHEN, H-L. R. "Use of maturity method to estimate compressive strength of mass concrete". Construction and building materials, pp.802-812, 2015.

[31] SOUTSOS, M.N., TURU'AlLO, G., OWENS, K., et al. "Maturity testing of lightweight selfcompacting and vibrated concrete"s. Constructing and building materials, vol 47, p.118-125, 2013.

ORCID

Roberto Luiz Curra

Fernanda Pacheco

Hinoel Zamis Ehrenbring

Roberto Christ

Jeferson Ost Patzlaff

Rafael Trevisan

Bernardo Fonseca Tutikian https://orcid.org/0000-0002-1308-2557

https://orcid.org/0000-0003-3455-491X

https://orcid.org/0000-0002-0339-9825

https://orcid.org/0000-0003-1367-8972

https://orcid.org/0000-0003-2699-0981

https://orcid.org/0000-0001-6591-2826

https://orcid.org/0000-0003-1319-0547 